\section{ЗНАЧЕННЯ ВИМІРЮВАННЯ ПРОДУКТИВНОСТІ ПОРТУ ДЛЯ ЗАБЕЗПЕЧЕННЯ ЙОГО ЕФЕКТИВНОГО УПРАВЛІННЯ}

МАКАРЕНКО М. В., доктор економічних наук, професор, Азовський морський інститут національного університету «Одеська морська академія»

БАРСЬКИЙ І. М., аспірант, Донецький державний університет управління
THE VALUE OF PORT

PERFORMANCE MEASUREMENT TO ENSURE ITS EFFECTIVE MANAGEMENT

\author{
MAKARENKO M., \\ Doctor of Science in Economics, \\ Professor, Head of the Department \\ of Management and Business on a \\ Sea Transport, Azov Maritime \\ Institute National University \\ "Odessa Maritime Academy" \\ BARSKYI I., \\ Post-graduate Student, Donetsk \\ State University of Management
}

У статті доведено зв'язок між продуктивністю порту та розвитком морських перевезень ци міжнародної торгівлі. Проведено аналіз науково-практичної літератури щзодо результативності та ефективності портів. Запропоновані принципи проєктування системи вимірювання продуктивності порту.

Ключові слова: продуктивність порту, результативність та ефективність, ефективність системи, прийняття рімень, система показників.

В статье доказана связь между производительностью порта и развитием морских перевозок и международной торговли. Проведен анализ научно-практической литературы по результативности и эффективности портов. Предложенные принщипь проектирования системы измерения производительности порта.

Ключевые слова: производительность порта, результативность и эффективность, эффективность системы, принятие решений, система показателей.

The article proves the connection between port productivity and the development of maritime transport and international trade. The analysis of scientific and practical literature on the effectiveness and efficiency of ports. The design principles of the port productivity measurement system are proposed.

Keywords: port performance, efficiency and effectiveness, system efficiency, decision making, system of indicators.

Постановка проблеми. Технологічний розвиток та наукові дослідження призвели до швидкого зростання міжнародної торгівлі та обміну продуктами між країнами. Порти вважаються необхідним елементом прискорення торгових морських перевезень. Слабка продуктивність порту призводить до зменшення 
обсягів торгівлі. Отже, важливо постійно покращувати ефективність роботи основних елементів морської галузі, а саме портів і суден. Вимірювання результативності є важливим для ефективного управління підприємствами.

Аналіз останніх досліджень та публікащій. Вимірювання ефективності допомагає менеджерам приймати обгрунтовані та виважені рішення, тому йому присвятили свої праці такі науковці, як: Тонган Дж. [1], Бічоу К. [2], Марлоу П. [3], Нілі А. [4], Ментзер Дж. [5], Бімон Б. [6], Ломан С.[7], Морган С. [8] та інші. Вчені підкреслюють, що вимірювання результативності стає важливим фактором ефективного планування, діагностики проблем та виявлення прогресу розвитку підприємства. Але, на наш погляд, слід підкреслити галузеві особливості вимірювання ефективності та результативності, тому дослідження в цій сфері продовжуються.

Метою статmі $\epsilon$ встановлення значення вимірювання продуктивності порту для забезпечення його ефективного управління.

Виклад основного матеріалу дослідження. У портових дослідженнях результативність кожного елемента морської галузі впливає на морську торгівлю, а отже, і на міжнародну торгівлю. Системи вимірювання допомагають оцінити, наскільки існуюча пропускна спроможність та продуктивність порту відповідають вимогам вантажовідправників та власників суден з точки зору часу очікування судна та ступеня задоволеності очікуванням одержувачів щодо тривалості перебування вантажу. Ефективна система вимірювання продуктивності допомагає контролювати ефективність операцій та терміналів у порту, забезпечуючи порт індикаторами, які допоможуть оцінити продуктивність порту та керувати складними операціями. Менеджери портів, планувальники та органи влади потребують надійної системи вимірювання ефективності для оцінки ефективності та результативності їхніх дій. 3 цієї причини оптимізація обладнання та експлуатації $є$ загальною метою більшості сучасних вимірювальних систем. Аналітичні методи, такі як моделі масового обслуговування, стохастичні мережі, аналіз даних, імітаційні моделі були найпоширенішими підходами, що використовуються при вимірюванні продуктивності портів. Нині у портах і терміналах використовується ряд вимірювальних систем.

У літературі вказується, що існує розрив у знаннях, оскільки традиційні та нещодавно розроблені системи вимірювання, як правило, суперечливі та не мають фокусу на вимірюванні загальної продуктивності портів. Більшість систем вимірюють контейнерні вантажі, контейнерні порти та контейнерні термінали. Порт має безліч терміналів i, як правило, обробляє більше одного типу вантажу: сухий наливний, контейнери та генеральний вантаж та інші. Зосередження уваги на вимірюванні одного виду вантажу не відображає загальних показників порту. Отже, останні вимірювальні системи не можуть відповідати стратегічним напрямкам порту. Тонган Дж. [1] стверджував, що «в кількох дослідженнях було виявлено деякі показники та фактори, які впливають на ефективність роботи порту, і що вони не змогли кількісно оцінити ці фактори для загальної ефективності». Бічоу К. [2] заявили, що: «Здається, можуть виникнути методологічні труднощі при прив'язуванні вимірювань продуктивності ланцюжка поставок до портів. Потрібен системний підхід до продуктивності портів». Існує потреба у розробці більш ефективної системи 
вимірювання продуктивності. Ця система повинна бути чітко пов'язана 3 оперативною стратегією порту та з низкою ключових змінних продуктивності.

Вимірювання продуктивності порту відіграє важливу роль у плануванні та контролі його роботи. Проведений огляд літератури 3 метою концептуального проєктування систем вимірювання продуктивності в портах, дозволив дійти висновку, що поточні системи вимірювання обмежені, і існує потреба у розробці надійної системи вимірювання, щоб заповнити цю прогалину. Тому дослідницьке питання було встановлене, щоб сприяти розвитку знань, і підхід був визначений як дедуктивний підхід с застосуванням кількісних підходів.

Кількісні методи традиційно використовуються для оцінки роботи порту Марлоу П. [3]. Були використані різні техніки, включаючи: економетричні, інженерні, методи дослідження операцій, статистичні методи, імітаційні моделі, моделі масового обслуговування, математичні моделі та регресійний аналіз [1]). Дослідження призначене для обговорення поточних систем вимірювання, що застосовуються у портах, та оцінки ефективності поточних показників ефективності роботи порту. Отже, практика затребувала застосування надійної та ефективної системи вимірювання продуктивності. Ці системи можуть допомогти прогнозувати, контролювати та планувати діяльність порту, а отже, підвищувати конкурентоспроможність. Формування більш ефективної системи вимірювання продуктивності призведе до поліпшення роботи в порту. Усе починається з аналізу систем вимірювання продуктивності. Спочатку аналізуємо сучасні системи вимірювання ефективності, що застосовуються в контексті ланцюгів поставок. Пояснюються різні поняття продуктивності, показника ефективності та систем вимірювання продуктивності. Дискусія зосереджена на поясненні різних конструкцій систем вимірювання продуктивності та різних категорій показників ефективності. Після цього проводиться оцінка поточних систем вимірювання продуктивності, що використовуються в портах. Також розглядається оцінка регресійних моделей та інших аналітичних інструментів, що використовуються для кількісної оцінки факторів, які можуть вплинути на ефективність роботи в портах. У контексті ланцюга поставок постачальники, виробники, дистриб'ютори та клієнти взаємопов'язані мережею, що забезпечує надійний потік інформації та матеріалів. Отже, ланцюги поставок можуть характеризуватися своєю складністю та невизначеністю у своїй діяльності. Моделювання таких ланцюгів поставок $є$ складним завданням. Для кількісної оцінки ефективності ланцюжка поставок на будь-якому підприємстві необхідно визначити, що мається на увазі, i розрізняти ефективність, вимірювання ефективності, показник ефективності та систему вимірювання результативності.

Щодо категорії продуктивності, то тут слід звернути увагу на існування великої кількості визначень. Деякі вчені [4] говорять про відношення фактичного випуску до стандартного випуску, що вимагає встановлення мети та стратегії для досягнення такого стандартного випуску. Вони обговорили, що продуктивність належать до співвідношення випуску продукції до вхідних ресурсів, тоді як використання - це відношення використаних об'єктів до наявних. Для досягнення стандартного виходу ціль прагне мінімізувати експлуатаційні витрати та поліпшити рівень обслуговування, що вимагає балансу між ефективністю та результативністю. Для обох цих вимірів вони 
вимірювали ефективність 3 точки зору того, наскільки ефективно використовуються ресурси, тоді як ефективність вимірювалася, якщо була досягнута ціль або стратегія. Нілі А. [4] та співавтори визначали ефективність як ефективність та результативність дій у контексті бізнесу Марлоу П. [3] загалом визначали результати як: «Дослідження ефективності та результативності у здійсненні даної діяльності та де оцінка проводиться щодо того, наскільки цілі були досягнуті». Вивчаючи попередні визначення категорії, очевидно, що вона має два виміри [4]: ефективність та результативність. Ефективність спрямована на задоволення вимог замовника, тоді як результативність $\epsilon$ мірою того, наскільки економічно використовуються ресурси фірми. Щодо вимірювання продуктивності, Ментзер Дж. [5] визначили це як аналіз ефективності та результативності даного завдання. Нілі А. [4] визначив вимірювання ефективності як «процес кількісної оцінки ефективності та результативності дії». Вони стверджували, що результативність може бути процесом, що використовується для кількісної оцінки ефективності та результативності. Бімон Б. [6] підкреслив, що вимірювання ефективності є інструментом перевірки ефективності та результативності існуючої або пропонованої системи. Вимірювання може відбуватися шляхом визначення значення змінних рішення, що дають рівень ефективності. Ломан С. [7] визначив вимірювання ефективності як діяльність, яку менеджери можуть використовувати для виконання своїх заздалегідь визначених цілей. Отже, вони стверджували, що вибір показників ефективності повинен виходити зі стратегії та цілей компанії. Морган С. [8] визначив ефективність роботи як заздалегідь визначені параметри, а оцінку ефективності визначив як здатність суттєво контролювати діяльність. Визначено, що вимірювання продуктивності як процес кількісної оцінки ефективності та результативності дій частини системи або процесу. Щодо вимірювання ефективності, Нілі А. [4] визначили його як невід'ємний елемент циклу планування та контролю в організаціях, і його можна використовувати для кількісної оцінки ефективності та результативності дій.

Для системи вимірювання ефективності іiі можна визначити як набір метрик, що використовуються для кількісної оцінки як ефективності, так і результативності дії [4] визначив систему вимірювання результативності як «інформаційну систему, яка має вирішальне значення для ефективного та результативного функціонування управління ефективністю». Нілі та співавтори (2002) визначив систему вимірювання результативності як збалансовану та динамічну систему, яка забезпечує підтримку процесу прийняття рішень шляхом збору, опрацювання та аналізу інформації. Бічоу К. [2] стверджували, що система вимірювання результативності - це багатовимірний набір показників ефективності для планування та управління бізнесом. Вони визначили систему як набір метрик, що використовуються для кількісної оцінки ефективності та результативності дії. Визначив систему вимірювання ефективності як сукупність заходів, що використовуються для вимірювання ефективності вжитих дій. Для розробки нової системи вимірювання продуктивності потрібно три етапи, включаючи проєктування, впровадження та використання. Крім того, вони стверджували, що додавання нових заходів до існуючих заходів у будь-якій системі збільшить складність, а отже, це призведе до застарілих систем. Однак збільшення кількості мір допомагає визначити масштаб, оскільки система 
вимірювання залежить від обсягу елементів та змінних. Крім того, збільшення кількості заходів у системі допомагає надати більше інформації про всі аспекти комунальних послуг у порту.

Таким чином, були розроблені різні підходи до вимірювання продуктивності з використанням різних методів та метрик для створення систем, таких як збалансована система показників (BSC), піраміда продуктивності, модель макропроцесу, призма продуктивності [4] та макро-мікросистема вимірювання продуктивності. Однак є такі, що у свій час стверджували, що жодне з визначень систем вимірювання продуктивності не має узгодженого набору характеристик. Отже, необхідно розуміти характеристики вимірювання продуктивності, категорії та конструкції.

Для характеристики таких систем, як послідовність, вартість, швидкість реагування споживачів, час діяльності та гнучкість, було використано велику кількість різних типів показників ефективності Бімон Б. [6]. Попередні дослідження були зосереджені на категоризації показників ефективності, таких як вартість та якість. Розуміння характеристик вимірювання та категорій показників допомагає особам, які приймають рішення, аналізувати, а також модернізувати системи вимірювання продуктивності відповідно до динамічного середовища бізнесу. Іншими словами, вимірювальні характеристики можна використовувати для оцінки системи визначення ефективності. Відзначено всеохопність, універсальність, вимірюваність та послідовність як основні характеристики показників ефективності. Він виділив три типи заходів як основні компоненти системи вимірювання результативності, а саме вимірювання ресурсів, вимірювання обсягу виробництва та міри гнучкості. Відзначають простоту та актуальність як дві характеристики ефективного вимірювання продуктивності. Вони зосереджувались на тому, щоб забезпечити низьку складність системи. Щодо категорій вимірювання продуктивності, було узагальнено різні категорії показників ефективності, які були розроблені протягом багатьох років. Були розроблені різні категорії показників ефективності відповідно до ряду характеристик. Зі стратегічної точки зору організації, Нілі А. [4] представив кілька категорій, серед яких: якість, час, гнучкість та вартість. Ментзер Дж. [5] визначив вартість як єдину категорію вимірювання ефективності. 3 іншого боку стверджували, що найкращим підходом було розпочати з п'яти загальних категорій вимірювань.

Попередні категорії мали на меті зрозуміти драйвери витрат організації. Зазначається, що ці категорії включають вартість як основний показник в системі вимірювання результативності. Метою є зробити бізнес-процеси більш ефективними, керуючи виробничими витратами та вартістю послуг, що надаються, і грошовим потоком. Однак ці заходи спрямовані на виробничу стратегію, яка не застосовується ні в інших організаціях, ні підтримує інші стратегії в рамках тієї самої організації. Нілі А. [4] стверджували, що проектування системи вимірювання продуктивності - це процес, коли виробляються вхідні та вихідні дані. Вхідні дані фіксуються у формі вимог, а вихідні - у вигляді показника ефективності. Вони розробили аркуш обліку результатів вимірювання, щоб допомогти у структуруванні системи вимірювань та у спрощенні проєктування систем вимірювання продуктивності. 
Конструкція системи вимірювання ефективності повинна відповідати цілям компанії. Пропонувались наступні сім принципів проєктування системи вимірювання продуктивності: заходи повинні бути безпосередньо пов'язані зі стратегією фірми; слід прийняти нефінансові заходи; слід визнати, що заходи різняться залежно від місця розташування; заходи змінюються в залежності від обставин; заходи повинні бути простими у використанні; заходи повинні забезпечувати швидкий зворотний зв'язок; заходи повинні стимулювати постійне вдосконалення, а не просто контролювати.

Висновки і перспективи подальших досліджень. Протягом останніх років дослідники демонструють зростаючий інтерес до вдосконалення систем вимірювання продуктивності. Для характеристики таких систем, як послідовність, вартість, швидкість реагування споживачів, час діяльності та гнучкість, було використано велику кількість різних типів показників ефективності. Попередні дослідження були зосереджені на категоризації показників ефективності, таких як вартість та якість. Розуміння характеристик вимірювання та категорій показників ефективності допомагає приймати обгрунтовані рішення, аналізувати, управляти та контролювати системи вимірювань, а також модернізувати вимірювання продуктивності відповідно до динамічного середовища бізнесу.

\section{References:}

1. Tongzon J. Port Choice and Freight Forwarders. Transportation Research Part E. 45, 2009, pp.186-195.

2. Bichou K. and Gray R. A Logistics and Supply Chain Management Approach to Port Performance Measurement. Maritime Policy and Management. 2004. 31(1), pp. 47-67.

3. Marlow, P. and Casaca, A. Measuring Lean Ports Performance. International Journal of Transport Management. 1. December 2003, pp. 189-202.

4. Neely A. The evolution of performance measurement research: developments in the last decade and a research agenda for the next. International Journal of Operations and Production Management. 2005. 25 (12), pp. 1264-1277.

5. Mentzer J. and Konrad B. An efficiency/effectiveness approach to logistics performance analysis. Journal of Business Logistics. 1991. 12 (1), pp. 33-61.

6. Beamon B. M. Performance measures in supply chain management. In: The Conference on Agile and Intelligent Manufacturing Systems, October 2-3, 1996. New York, USA. NY: Troy. Rensselaer Polytechnic Institute.

7. Lohman C., Fortuin L. and Wouters M. Designing a performance measurement system: a case study. European Journal of Operational Research. 2004. 156, pp. 267-286.

8. Morgan C. Structure, speed, and salience: performance measurement in the supply chain. Business Process Management Journal. 2004.10 (5), pp. 522-536.

The article emphasizes that in port research, the effectiveness of each element of the maritime industry affects maritime trade and international trade. Performance measurement becomes an important factor in effective planning, problem diagnosis, and identification of enterprise development progress. 
In recent years, researchers have shown a growing interest in improving performance measurement systems. To characterize such systems, a large number of different types of performance indicators were used. Previous research has focused on categorizing performance indicators such as cost and quality. The literature notes that there is a knowledge gap, as traditional and newly developed measurement systems are generally inconsistent and do not focus on measuring overall port performance. The latest measuring systems cannot correspond to the strategic directions of the port. Understanding measurement characteristics and categories of performance indicators helps to make informed decisions, analyze, manage and control measurement systems, and modernize performance measurements according to a dynamic business environment. Measurement systems help to assess the extent to which the existing port capacity and capacity meet the requirements of shippers and shipowners in terms of ship waiting time and the degree of satisfaction with recipients' expectations regarding the length of stay of cargo.

It is necessary to develop a more effective performance measurement system. This system should be clearly linked to the port's operational strategy and several key performance metrics. The study is designed to discuss current measurement systems used in ports and to assess the effectiveness of current port performance indicators. The practice required the use of a reliable and efficient performance measurement system. Approaches to performance measurement using different methods and metrics are analyzed. Therefore, it is necessary to understand the characteristics of measuring performance, category and design. The principles of designing a performance measurement system are proposed. 